\title{
Sediment Study in Western part of Himalayan Watershed Using Remote Sensing and GIS
}

\author{
Jaivir Singh, B.R. Singh, Samsher, S.K.Jain ${ }^{1}$ and Sandip Shukla ${ }^{1}$ \\ Deptt of Agril. Engg. and Food Technology, SVPUA\&T, Meerut (UP) \\ ${ }^{1}$ National Institute of Hydrology, Roorkee \\ * Email: jaivir_yadav@yahoo.co.in
}

\begin{abstract}
The present study was carried out to sediment study in western part of Himalayan watershed using remote sensing and GIS from Rampur to Kasol are considered in Himachal state with the two objectives: (i) To estimate the runoff and sediment yield using Arc SWAT (Soil and Water Assessment Tool). (ii) To validate the estimated runoff and sediment yield for the watershed. Application of Arc SWAT 2005 in integration with Remote Sensing and GIS to estimate the runoff, sediment yield and other hydrological parameters of the area Rampur and Kasol an intermediate basin of Satluj river located in western Himalayan regions in India. The DEM was generated to prepare slope map. The Soil Map was prepared from NBSS \& LUP soil map with a scale of 1:500,000. About 60.45 percent of s oil area falls under Fine-Loamy soil having Hydrological group-D and 1794 percent of soil area falls under Course Loamy soil with hydrological Group-D. In the study area 26 sub watersheds are formed. The area delineated by the Arc SWAT interface was found to be 81761 ha against the manually delineated area of 81790 ha. The error of calculation was found to be $0.01 \%$. Rampur to Kasol an intermediate basin of Satluj river was used to estimate the runoff and sediment yields for the data of mainly eleven years from 1990 to 2000 . The calibration period reported the value of $\mathrm{R}^{2}$ is 0.55 and 0.92 for daily and monthly results. The values of Nash-Sutcliffe $\mathrm{R}^{2} \mathrm{NS}$ for daily and monthly results were found to be 0.74 and 0.87 , respectively. The model estimated results showed the correlation during sediment calibration having $\mathrm{R}^{2}$ value are $0.35 \& 0.40$ for daily and monthly basis respectively. The graphical validation analysis showed the $R^{2}$ values is 0.65 for monthly runoff values for 1998 to 1999 with $R_{N S}$ values 0.46 and 0.66 for daily and monthly respectively. The validated $R^{2}$ value was observed to be 0.50 for monthly sediment yield values for 1998 to 1999 respectively. There is reasonably good results between estimated and observed daily and monthly data for these years and for the current study basin from Rampur to Kasol. During the year 1995, 1996 and 1997 the simulated runoff was $992.10,823.90 \& 990.20(\mathrm{~mm})$ respectively as against the observed runoff of $1039.90,1336.651 \&$ $1272.035(\mathrm{~mm})$ from a total rainfall of $1456,1358 \& 1650(\mathrm{~mm})$ correspondingly. The graphical analysis showed the $R^{2}$ values is 0.62 for monthly runoff values for 1998 to 2000 having $R^{2}{ }_{\text {NS }}$ values 0.46 and 0.66 for daily and monthly respectively. This might be due to less numbers of rain gauge stations within the study area, as in the upper reach of the basin. The other reason may be the inaccuracy of the observed data as in few months surface runoff has been observed. Validation has also been done for daily and monthly sediment yield for the year 1998, 1999 and 2000. It was observed that the model has predicted more sediment load in most of the events. The $\mathrm{R}^{2}$ value was observed as 0.50 for monthly sediment yield values for 1998 to 2000 respectively. The total simulated sediment yield was observed to be $40.124,25.35 \& 48.664$ (t/ha) as against the observed sediment yield of $133.245,145.850 \& 140.565$ (t/ha) respectively for the validated year 1998 to 2000 .
\end{abstract}

Key words: GIS, Himalayan, Remote sensing, Sediment, watershed,

Paper cited: Singh, J., Singh, B.R., Samsher; Jain, S.K. and Shukla, S. (2015). Sediment Study in Western part of Himalayan Watershed Using Remote Sensing and GIS. South Asian Journal of Food Technology and Environment, 1(3\&4): 256-265

\section{Received: 17/09/2015 Revised: 29/09/2015 Accepted 11/10/2015}

\section{Introduction}

The rates of soil erosion and land degradation are a major concern issue in the western part of the Himalayan watersheds.
Soil erosion causes siltation of reservoirs, which ultimately reduces the life of the project and affects generation of hydroelectric power (Jasmine and Ravichandran, 2008). As per the Ministry of Agriculture, Govt. of India report 
(1985), about 113.3Mha of land is subjected to water erosion. The process of soil erosion is mainly affected by deforestation and urbanization. The variables such as climate, soil type, land use land cover, topography and anthropogenic activities influence soil erosion and sediment delivery in the watershed (Lee 2004; Lue et al., 2004). As a result of human mismanagement, the soils upon which men have attempted to find new civilizations are disappearing, washed away by water and blown away by wind. Throughout the world erosion is taking its relentless toll of soil fertility with incredible and ever increasing speed. Steep slopes, sparse vegetation, high rainfall intensities and unstable geology, coupled with one of densest human populations, have combined to produce some of the highest reported soil erosion rates in the entire Himalayan region (Srivastava et al., 2006; Manoj et al., 2003). Various efforts have been made to determine the soil erosion rates in the Himalayan watershed by using Arc SWAT. (Shrestha, 1997) observed soil losses ranges from $<1 \mathrm{Mg} / \mathrm{ha} / \mathrm{yr}$ for dense forest to 56 $\mathrm{Mg} / \mathrm{ha} / \mathrm{yr}$ for a Himalayan watersheds in Nepal using MMF model (Morgan, Morgan and Finney Model. ( Kumar and Sharma, 2002) used the MMF model to assess soil erosion from a western Himalayan watershed and found soil losses ranging from $3.5 \mathrm{Mg} / \mathrm{ha} / \mathrm{yr}$ for dense forest to $92.6 \mathrm{Mg} / \mathrm{ha} / \mathrm{yr}$ for steep open scrub.The Himalayan regions have greatly deteriorated from intensive deforestation, largescale road construction, mining, and cultivation on steep slopes. The young Himalayas have a serious problem of soil erosion in the upper reaches and sedimentation in river reaches downstream. A large number of reservoirs have been constructed in Himalayas for hydroelectric power generation, domestic water supply, irrigation, flood mitigation etc. Excessive siltation due to accelerated erosion is threatening the lives of these projects. This has considerable economic significance since the reduced soil depth leads to loss of nutrients, decline in crop productivity and downstream transport of eroded sediment leads to raising of riverbeds and decrease in reservoir capacities. The significant difference in the river dynamics, topography, geology, and size of material of the mountainous areas to those in the plains has a major effect on the characteristics of the sediments. Suitable methodologies should be evolved for an integrated approach in watershed resources development and management. Erosion in nature is a beneficent process, without which the world would have died long ago. The same process accelerated by human mismanagement, has become one of the most vicious and destructive forces that have ever been released by man. As each superficial film of plant covered soil becomes exhausted, it is removed by wind or rain to be deposited mainly in the rivers and sea and a corresponding thin layer of new soil forms by the slow weathering of the underlying rocks. In this way equilibrium is reached between denudation and soil formation. The equilibrium between denudation and soil formation is easily disturbed by the activities if man like cultivation, deforestation, or destruction of the natural vegetation etc. This man accelerated denudation is what is now known as soil erosion (Jack, 1986).

The chain of the Himalayan Mountains acts as an effective barrier to the summer monsoon and westerly winter disturbances. The major river systems of India, the Indus, Ganges and Brahmaputra have their origin in the Himalayan mountain region. The availability of high runoff coupled with wide variations in elevations provides a large potential for hydroelectric power.

Himalayan region is witnessing a large economic growth and demands for irrigation water, hydro-electricity are ever increasing. At the same time, transportation of high sediments from the Himalayan Basin is also one of the serious problems for any water resources development project. The Indian Himalayan region, which is more than $2,800 \mathrm{~km}$ in length and 220 to $300 \mathrm{~km}$ wide, is spread over the states of Jammu \& Kashmir, Himachal Pradesh, Sikkim, Arunachal Pradesh, Nagaland, Manipur, Mizorum, Tripura, Meghalaya and a part of Assam, along with eight districts of Uttarakhand and one district of West Bengal. 
The Himalayan mountain chain has a dominant influence on the climatic conditions prevailing over Indian sub-continent. They lie in the path of rain-bearing monsoon winds and thus bring rain to a large part of India. The Himalaya houses a vast reservoir of moisture both in the form of ice, fresh-water and underground water. The rivers draining the Himalayas sustain life in the Northern part of the Indian sub-continent. The drainage system of Himalaya is very complex. It is composed both of rivers and glaciers. Himalayan rivers -cross the entire mountain chain. In fact a number of rivers are older than the mountain system. They have cut across the various mountain ranges. In Himachal, rivers from two rivers systemsIndus River System (Satluj, the Beas, the Ravi, the Chenab and the Jhelum) and Ganga River System (only river Yamuna) flow through. Satluj rises from beyond Indian borders in the Southern slopes of the Kailash mountain near Mansarover lake from Rakas lake, as Longcchen Khabab river (in Tibet). It is the largest among the five rivers of Himachal Pradesh. It enters Himachal at Shipkila (altitude is 6,608 meters) and flows in the SouthWesterly direction through Kinnaur, Shimla, Kullu, Solan, Mandi and Bilaspur districts. Its course in Himachal Pradesh is $320 \mathrm{~km}$. from Rakastal, with famous tributaries viz. the Spiti, the Ropa, the Taiti, the Kashang, the Mulgaon, the Yula, the Wanger, the Throng and the Rupi as right bank tributaries, whereas the Tirung, the Gayathing, the Baspa, the Duling and the Soldang are left bank tributaries. The prominent human settlements that have come on the banks of the Satluj River are Namgia, Kalpa, Rampur, Tattapani, Suni, Ksaol and Bilaspur. Its total length is $1,448 \mathrm{~km}$. Its total catchment area from Rampur to Kasol of intermediate basin of Satluj river is $2768 \mathrm{sq} \mathrm{km}$.

The capacity of the reservoirs located in this region reduces at an alarming rate due to deposition of sediment, thus adversely affecting the optimal operation of the water resources schemes. The significance difference in the river dynamics, topography, geology and size of material of the mountainous areas to those in the plains has a major effect on the characteristics of the sediment yield and runoff also. In India a total of $1,750,000 \mathrm{sq} \mathrm{km}$ out of the total land area of $3,280,000 \mathrm{sq} \mathrm{km}$ is prone to soil erosion. Thus about $53 \%$ of the total land area of India is prone to erosion and increasing year to year. The mean annual erosion rate varies from $350 \mathrm{t} \mathrm{km}^{-2}$ to $2500 \mathrm{t} \mathrm{km}^{-2}$. The reliable prediction of the various hydrological parameters including runoff and sediment yield for remote and inaccessible areas are tedious and time consuming by conventional methods. So it is desirable that for hydrologic evaluation of watersheds, some suitable methods and techniques are to be used/ evolved for quantifying the hydrological parameters from all parts of the watersheds. Use of mathematical models for hydrologic evaluation of watersheds is the current trend and extraction of watershed parameters using remote sensing and geographical information system (GIS) in high speed computers are the aiding tools and techniques for it.

In the present study, soil erosion and sediment yield from Rampur to kasol Himalayan watershed are considered.

\section{Study area}

In the present study, two watersheds Rampur and kasol have been taken up as case study for soil erosion and sedimentation studies. The details of the watershed, data collected and analysis has been described in the following section.

Satluj river basin: The Satluj river originates from Rakas-Tal Lake which is fed by Lake Mansrover in Tibet at an altitude of about $4572 \mathrm{~m}$ above mean sea level. Between Raskas-Tal and Ship Ki near the Indian border the Satluj river follows a North westerly direction for a length of about $322 \mathrm{~km}$ in the Tibetan province of Nari-Khorsam. It is joined by several tributaries in Nari-Khorsam, the bed of which are lower by about $305 \mathrm{~m}$ than the general level of the plateau. Their vertical cliffs, like those of Satluj, have been spared from destruction by rain, and flat portions of the plateau now remain standing between deep and narrow gorges.

The total geographical area of Satluj catchment upto Bhakhra dam is about 56,980 
$\mathrm{km}^{2}$ of which about $37,153 \mathrm{~km}^{2}$ lies in Tibet. The rest about $19,827 \mathrm{~km}^{2}$ lies in the Indian Territory. The major portion of the Satluj basin lies in the greater Himalayan range. The bed slope of Satluj from its source to Bhakhra dam site is quite uniform. The elevation of the bed is $4572 \mathrm{~m}$ near Rakas-Tal, $3048 \mathrm{~m}$ near Ship-Ki, $914 \mathrm{~m}$ at Rampur, $457 \mathrm{~m}$ at Bilaspur and $347 \mathrm{~m}$ at the Bhakhra Dam site. The river oed slope in the reservoir area is about 1.89 to $2.27 \mathrm{~m} / \mathrm{km}$. The river leaves the Himalayas near Nangal, where Nagal barrage is located.

The study area is located in the western part of Himalayan watershed, Himachal state in India. For the present study relationship between sediment yield and discharge has been developed for the intermittent basin from Rampur to Kasol. Sediment yield estimation has been carried out for the area from Rampur to Kasol. This area falls in the lower part of the Satluj basin. Kasol is almost at the tip of the reservoir. This area comes in the lower shiwaliks with mountain peaks up to $2134 \mathrm{~m}$ height and the rainfall in this region is heavy i.e. $913 \mathrm{~mm}$ to $1635 \mathrm{~mm}$. This area being more populated than the higher regions has poor forests and more cultivation and this sediment yield is the heaviest. The study area is shown in Fig.1

In the present study, assessment of sediment yield has been made for the Satluj river, which flows through the western Himalayan region. The western Himalayas cover the hilly areas of Jammu-Kashmir, Himanchal Pradesh and Uttarakhand in India. Two important river systems originated from the western Himalayan region are Indus system- Indus, Jhelum, Chenab, Ravi, Beas and Satluj and Ganga system- Yamuna, Ramganga, Sarda, and Karnali. These rivers are fed by snowmelt and rainfall during the summer and by groundwater flow during the winter.

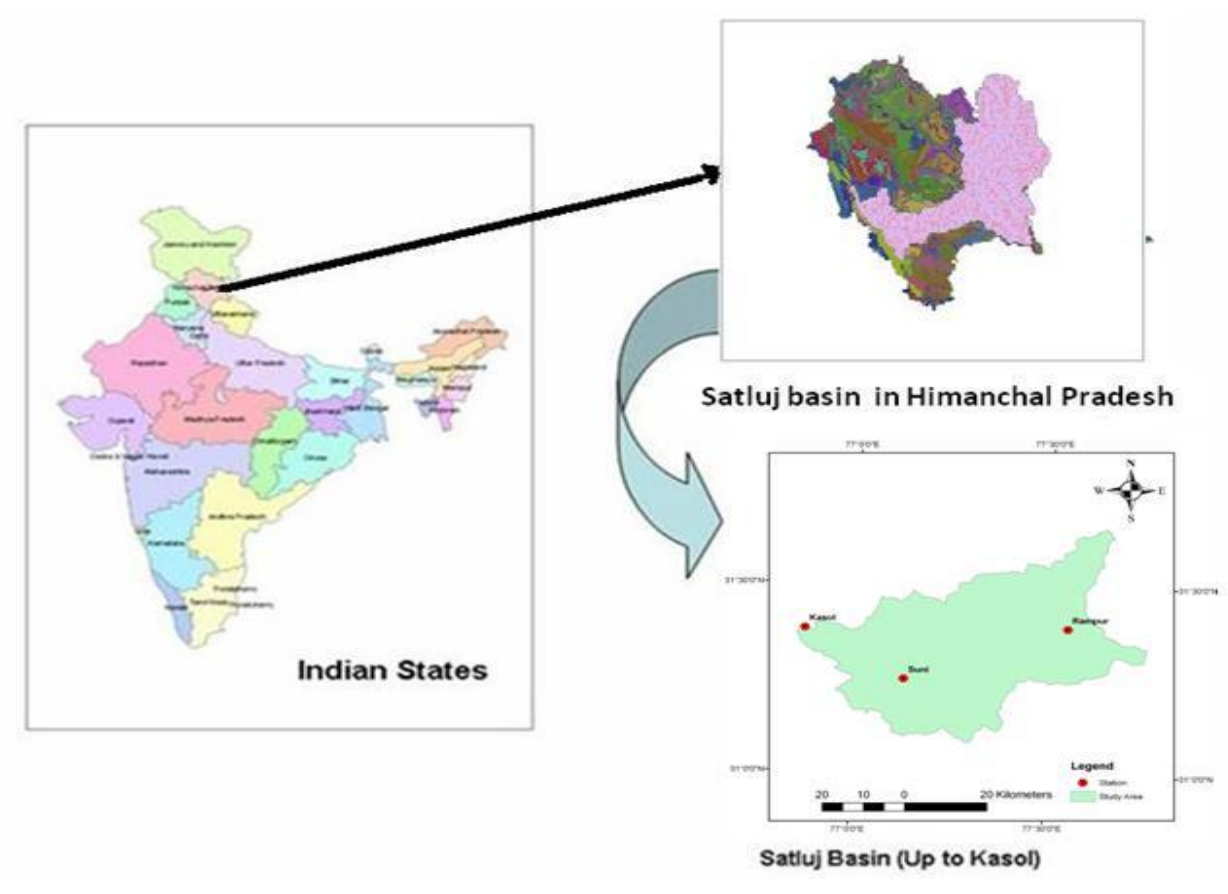

Fig.1: Study area from Rampur to Kasol an intermediate basin of Satluj river

Data Availability: For the present study, field data of rainfall, discharge and sediment yield have been collected from BBMB, Nangal and
National Institute of Hydrology (NIH) Roorkee. The rainfall data of the two stations, namely Rampur and Kasol, which are falling 
in the study area, were collected. The study area comprises the area between Rampur to Kasol, covering an area of about $2768 \mathrm{~km}^{2}$, therefore discharge and suspended sediment data have been compiled from daily records maintained at Rampur and Kasol. The runoff and sediment derived from the intermittent catchment i.e. from Rampur to Kasol were obtained by subtracting the contributions at Rampur to Kasol. The database were prepared for a period of ten years from 1990-2000.

Remote Sensing Data: Remote Sensing data in the form of Standard FCC (False Coloure Composite) was available at NIH (National Institute of Hydrology). For this study, Landsat ETM+ (P/R-147/38-2008) with $30 \mathrm{~m}$ resolution (for multispectral) and IRS, AWiFS (56 $\mathrm{m}$ resolution) data were used.

\section{Software used}

ERDAS Imagine 9.3: The ERDAS (Earth Resources Data Analysis System) Imagine 9.3, an image processing software having few capabilities of GIS has been extensively used for importing and exporting of images from one format to another, rectification of imageries, sub setting of images and preparation of thematic maps.

Arc GIS 9.3: Arc GIS include a suite of integrated applications that allow you to perform GIS tasks, from simple to advanced, including mapping, geographic analysis, data editing and compilation, data management, visualization, and geoprocessing.

ArcView3.2a: In the present study Arc View GIS software developed by ESRI (Environmental Systems Research Institute) has been used extensively for arranging all the layers in proper sequence (.shp format).

\section{Creation of data base}

Demarcation, Scanning and Digitization of the Study Area: The study area from Rampur to Kasol an Intermediate Basin of Satluj river was delineated from four Survey of India toposheets of 1:50000 scales based on the ridge line, drainage, elevation \& pattern. The delineated boundary was then traced over a tracing paper with the coordinates (tic points) of the toposheets being accurately marked on it. The traced map was then scanned in an A0 scanner at a resolution of $300 \mathrm{dpi}$. The scanned map was then geometrically corrected based on 32 ground control points in ERDAS Imagine software. The geometrically scanned map was then digitized onscreen to prepare the boundary and drainage map of the basin. Then all errors including dangles were removed from the coverage's by the process of radiometric and geometric corrections. The boundary was cleaned and built as polygon using the vector module of Arc GIS to know the area and perimeter of the basin. Topology was also constructed for the drainage map in order to know the length of each stream. Attribute information was entered in order to know the stream order \& pattern within the basin and for morphometric analysis.

Sediment Yield and Hydrological data processing: The daily observed discharge data (cumec) for the study area at the outlet were converted to the depth $(\mathrm{mm})$ of runoff by watershed area approach method. The observed sediment yield data (t/day) were converted into tons per hectare ( $\mathrm{t} / \mathrm{ha}$ ) using the watershed area. Sediment yield for the intermediate catchment between Kasol and Rampur were obtained by subtracting the contributions at Rampur and Kasol. The sediment yield and discharge in the catchment is high in the monsoon period, therefore silt load is also maximum in the river in these months. The concentration levels in the river cannot be generalized because it varies considerably from year to year and from month to month (Sharma et al., 1991). 


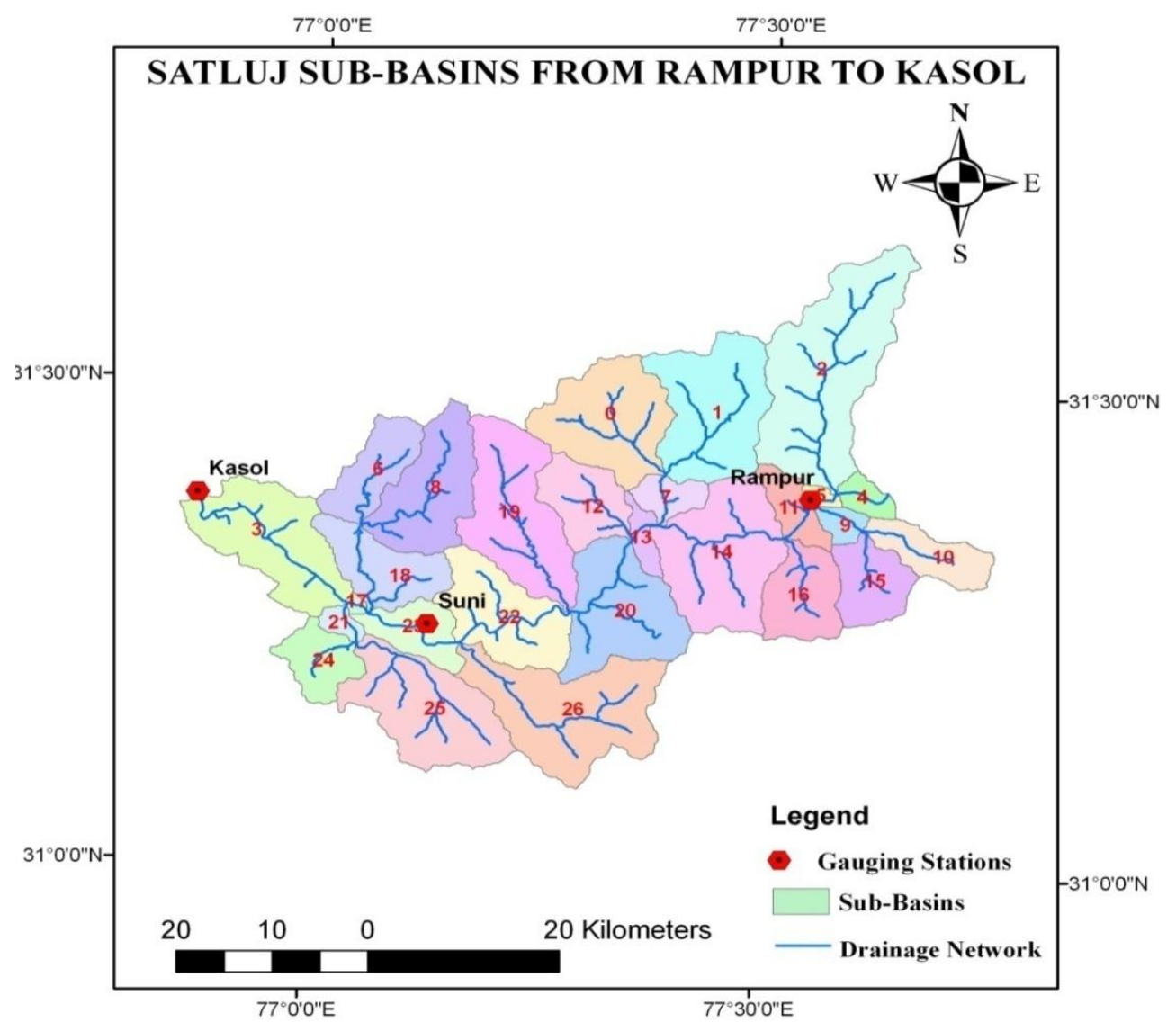

Fig. 2: Automatic delineated watershed sub basins by Arc SWAT of the study area from Rampur to Kasol

Model Calibration: Calibration is the process in which selected parameters and variables of the model are adjusted to make the model output match the observations. The main purpose of the calibration is to obtain an economical and reproducible method of identifying a parameter set for a particular catchment under particular conditions which gives the best possible fit between the simulated and observed stream flows for a particular calibration. The aims of the calibrated parameters are to minimize the difference between simulated and observed stream flows. Calibration is considered to be necessary because there may be uncertainties in the model input and because models give only simplified representations of the catchment's physical processes, which operate at a range of scales which are not always compatible with the catchment or grid scale. In the present study the Arc SWAT model was calibrated for the year 1996 \& 1997 based on the observed discharge and sediment data. During the calibrating of the model, various parameters such as Manning's ' $n$ ' (Manning's Roughness Coefficient), for overland flow, curve number, soil evaporation compensation factor (ESCO), available water capacity (AWC) and slope of sub-basin were taken into consideration within the prescribed limit of the model. Three parameters such as revap coefficient, specific yield and revap storage were also tried to calibrate the model. During the calibration it was observed that the model performance is not significantly affected on variation of values for these parameters. Therefore, either model default values or range of values suggested by model developers were used. Several simulations techniques were carried out after each parameter calibration till the simulated results were in good agreement with the observed results. More efficient and 
prescribed parameters can give more efficient results.

Model Validation: Model validation is defined as the process of re-running the simulation, using a different time-series for input data, without changing any parameter values which may have been adjusted during calibration. In the present study, after proper calibration the model was validated for monthly and daily surface runoff for the year 1998 to 2000.

\section{Performance evaluation for models}

Performance evaluation of models was done in order to compare how the model simulated values fits with the observed values. For the evaluations of hydrologic model, number of statistics techniques was used for model performance. Usually these tools known are as "goodness of fit" or relative error measures to assess the ability of a model to simulate reality. The following graphical and numerical performance criteria were used in the present study:

(1) The coefficient of determination $\left(\mathrm{R}^{2}\right)$ describes the proportion of the total variance in the measured data that can be explained by the model. It ranges from 0.00 to 1.00 , with higher values indicating better agreement, and is given by,

$$
R^{2}=\left[\frac{\sum_{i=1}^{N}\left[O(i)-O_{\text {avvg }}\right]\left[S(i)-S_{\text {avg }}\right]}{\left[\sum_{i=1}^{N}\left(O(i)-O_{\text {avg }}\right)^{2}\right]^{0.5}\left[\sum_{I=1}^{N}\left(S(i)-S_{\text {avg }}\right)^{2}\right]^{0.5}}\right]
$$

Where

$\mathrm{O}(\mathrm{i})$ is the $\mathrm{i}^{\text {th }}$ observed parameter, $\mathrm{O}_{\text {avg }}$ is the mean of the observed parameters, $\mathrm{S}(\mathrm{i})$ is the $i^{\text {th }}$ simulated parameter, $S_{\text {avg }}$ is the mean of model simulated parameter and $\mathrm{N}$ is the total number of events.

(2) Coefficient of simulation efficiency $\left(\mathrm{C}_{\mathrm{OE}}\right)$, also known as the Nash-Sutcliffe coefficient (Nash \& Sutcliffe, 1970) recommended by ASCE Task Committee (1993) is the second basic goodness-of-fit criterion used to evaluate the model performance. The equation is as follows:

$$
C O E=1-\frac{\sum_{i=1}^{n}\left(Q_{i}-Q^{\prime}{ }^{\prime}\right)^{2}}{\sum_{i=1}^{n}\left(Q_{i}-Q\right)^{2}}
$$

Where

$Q_{i}$ and $Q_{i}^{\prime}$ are the measured discharge and computed discharge, $\mathrm{Q}$ is the average measured discharge values. The values for $C_{O E}$ can be varied from 0 to 1 , with 1 indicating a perfect fit. A value for $C_{O E}$ equal to zero indicates that the model was simulating no better than using the average of the observed data.

\section{Results and discussion}

The study area from Rampur to Kasol, a mountainous basin of Satluj river was delineated from the SOI toposheets. Various input layers have been prepared from satellite images. The data base has been generated as per the requirement of the Arc SWAT model. The climate and soils data base were also prepared as per the input requirement of the model. Various hydrological components like surface runoff, sediment yield, ET, were simulated on daily, monthly \& yearly basis. The output of the model on daily, monthly and annual basis for surface runoff and sediment yield were compared with the observed one.

\section{Model calibration}

In the present study the Arc SWAT model was simulated yearly for the year 1993 to 1999 , calibrated for the year 1996 \& 1997 using the runoff and sediment yield data recorded at the outlet of the study area. The model was calibrated using different values of input parameters for available water content (AWC) and soil evaporation compensation factor within the prescribed range required by the model. Several simulation runs were applied until a goodness-of-fit between observed and simulated flow was obtained. In order to compare the simulated values with the observed values, the coefficient of 
determination $\left(\mathrm{R}^{2}\right)$ and Nash \& Sutcliffe $\left(\mathrm{R}_{\mathrm{NS}}^{2}\right)$ efficiency methods were applied.

The time series of the simulated and observed surface runoff were compared graphically for daily, monthly \& yearly basis. The results of the calibration period have been reported the values of $\mathrm{R}^{2}$ are 0.55 and 0.92 for daily and monthly respectively. The value of Nash-Sutcliffe $\mathrm{R}_{\text {NS }}^{2}$ for daily and monthly were found to be 0.74 and 0.87 respectively. By the graphical representation it was observed that the monthly comparison indicate a better correlation then the daily values. The daily calibrated graph between observed and simulated runoff during (1996 to 1997) are shown in fig.6.3. The Monthly calibrated graph between observed and simulated runoff during (1996 to 1997) are shown in fig.4. An attempt has also been made to calibrate the monthly sediment for the period 1996 \& 1997. For this calibration, the slope of the sub-basin has been considered, which is one of the most sensitive parameter for sediment load. The model estimation result showed the correlation value during sediment calibration $\mathrm{R}^{2}$ are 0.35 \& 0.40 for daily and monthly basis respectively. This may be due to the reasons that non-reliability of the observed sediment data. Another reason could be the number of delineated sub-basins as it has been observed that watershed subdivision has an effect on the sediment load.

\section{Model validation}

After completed the calibration process, the model was validated for the daily and monthly surface runoff for the year 1998 to 2000 with the corresponding measured rainfall data.During the year 1995, 1996 and 1997 the simulated runoff was $992.10,823.90$ \& $990.20(\mathrm{~mm})$ respectively as against the observed runoff of $1039.90,1336.651 \&$ $1272.035(\mathrm{~mm})$ from a total rainfall of 1456 , 1358 \& 1650 (mm) correspondingly. The graphical analysis showed the $\mathrm{R}^{2}$ values is 0.65 for monthly runoff values for 1998 to 2000 having $\mathrm{R}_{\text {NS }}^{2}$ values 0.46 and 0.66 for daily and monthly respectively. This might be due to less numbers of rain gauge stations within the study area, as in the upper reach of the basin. The other reason may be the inaccuracy of the observed data as in few months surface runoff has been observed. Validation has also been done for daily and monthly sediment yield for the year 1998, 1999 and 2000. It was observed that the model has predicted more sediment load in most of the events. The $R^{2}$ value was observed as 0.47 for monthly sediment yield values for 1998 to 2000 respectively. The total simulated sediment yield was observed to be 40.124 , $25.35 \& 48.664(\mathrm{t} / \mathrm{ha})$ as against the observed sediment yield of $133.245,145.850 \& 140.565$ (t/ha) respectively for the validated year 1998 to 2000. Fig.6.13 to 6.14 shown the Daily and monthly validated graph between observed and simulated runoff from (1998 to 2000) respectively.

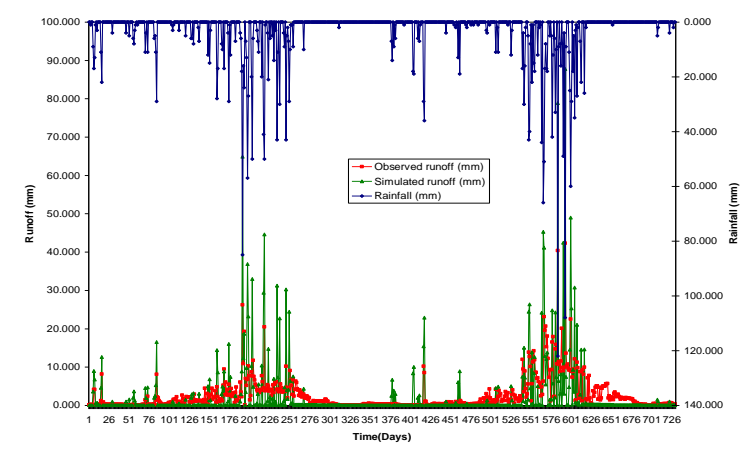

Fig.3: The daily calibrated graph between observed and simulated runoff during (1996 to 1997)

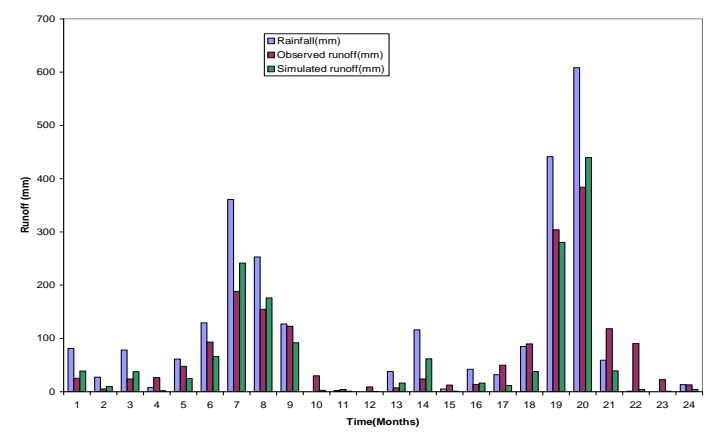

Fig.4: The Monthly calibrated graph between observed and simulated runoff during (1996 to 1997) 


\section{Conclusions}

Predicting the location of runoff and sediment source areas is of utmost importance for watershed management, location of runoff source areas vary according to type of runoff mechanism operating behind; thus characterization of area on basis of runoff mechanism helps in better understanding of the hydrological processes and consequently to identification of potential zones of run. The Himalayan region has the tremendous potential of natural resources which is given by God. Different types of schemes are under operation and some more are coming up in this region to harm natural resources. The proper assessment of stream flow and sediment estimation requires simple and systematic approaches keeping in view the limitations of data availability. The distribution of sediment yield and consequently runoff in the Satluj basin shows that the major contributions of sediment into stream flow occur in the summer session while in the winter session, it is significant. In the present study from Rampur to Kasol an intermediate basin of Satluj river was used to estimate the runoff and sediment yields for the data of mainly eleven years from 1990 to 2000 . The calibration period reported the value of $\mathrm{R}^{2}$ is 0.55 and 0.92 for daily and monthly results. The values of NashSutcliffe $\mathrm{R}^{2}$ NS for daily and monthly results were found to be 0.74 and 0.87 respectively. The model estimated results showed the correlation during sediment calibration having $\mathrm{R}^{2}$ value are $0.35 \& 0.40$ for daily and monthly basis respectively. The graphical validation analysis showed the $\mathrm{R}^{2}$ values is 0.65 for monthly runoff values for 1998 to 1999 with $\mathrm{R}_{\mathrm{NS}}^{2}$ values 0.46 and 0.66 for daily and monthly respectively. The validated $R^{2}$ value was observed to be 0.50 for monthly sediment yield values for 1998 to 1999 respectively. There is reasonably good results between estimated and observed daily and monthly data for these years and for the current study basin from Rampur to Kasol. In this approach physiographical characteristics of the basin were considered and required parameters were derived using remote sensing and GIS.

The sediment yield and runoff are generally produced due to the improper land and agricultural management practices and so on. The sediment yield generated in the higher reaches cause sedimentation on or the near situated basins. For the present study, the hydrological model SWAT (Soil \& Water Assessment Tool) was applied for the estimation of the runoff and resulted sediment yield. The weakness of the model is to simulate sediment was due to the improper peak runoff simulation and the nature and accuracy of the measured sediment data. Prediction of runoff and soil loss in the form of sediment is important for assessing soil erosion hazards, and for determining suitable land uses and soil conservation measures for a catchment. The result based on this approach reasonably agrees with the other approaches.

The runoff and sediment yield studies in other parts of the Himalayan watershed can also be conducted with approaches developed in this study. There is also much scope for application of the SWAT model a remote sensing and GIS based approach for assessment of sediment yield and runoff in the Himalayan basin and elsewhere. Past studies reveals that watershed subdivisions has an impact on predicted sediment yields mainly due to sensitivity of overland slope and slope length, channel slope and drainage density. Therefore, detailed study can be carried out to find its significance and suggest a threshold value beyond which watershed subdivisions is not having on sediment yield.

\section{References}

1. Jasmin, I. and Ravichandran, S. (2008). RUSLE model application for soil erosion assessment using remote sensing and GIS. Water Resource Management, 22: 83-102.

2. Lee, S. (2004). Soil erosion assessment and its verification using the Universal Soil loss Equation and geographical Information System. A case study at Boun Korea. Environmental Geology, 45: 457-465.

3. Srivastava, P., McNair, J. N. and Johnson, T.E. (2006). Comparison of process based and artificial neural network approaches for streamflow modeling in an agricultural watershed. 
Journal of American Water Resource Association, 42(2): 545-563

4. Jha, M., Gassman, Phillip W., Secchi, S. and Arnold, J. (2003). Initial calibration and validation of the SWAT model for the upper Mississippi river basin. Diffuse pollution conference, Dublin.

5. Shrestha, R.P., Apisit, E. and Somachai, B. (1997). Soil erosion assessment and its policy implicationsGIS development. net> AARS $>$ ACRS.

6. Sharma, J.C. and Sharma, K.R. (2002). Land use planning using RS \& GIS-A case study in Kawal Khad watershed in Himachal Pradesh. Indian Journal of Soil Conservation, 31(2):306-309

7. Jack, G.V, (1986). Soil erosion. In: Morgan, R.P.C, (eds) Soil erosion and its control. Van Nostrand Reinhold Company, New York.

8. Sharma, P.D., Goel, A.K. and Minhas, R.S. (1991). Water and sediment yields into the Satluj River from the High Himalaya. Mountain Research and Development, 11(2): 87-100. 